\title{
Attitude Competency Assessment in the 2013 Curriculum Based On Elementary School Prototyping Methods
}

\author{
Erick Febriyanto ${ }^{1}$, Romzi Syauqi Naufal ${ }^{2}$, Frizca Budiarty ${ }^{3}$ \\ Jurusan Sistem Informasi, STMIK Raharja, Tangerang \\ e-mail: erick@raharja.info' ${ }^{1}$,romzi@raharja.info² ${ }^{2}$,rizca.budiarty@raharja.info ${ }^{3}$
}

How to Cite:

Febriyanto, E., Naufal, R., \& budiarty, frizca. (2019). Attitude Competency Assessment in the 2013 curriculum based on elementary school Prototyping methods. IAIC Transactions on Sustainable Digital Innovation (ITSDI), 1(1), 87-96. Retrieved from https://aptikomjournal.id/index.php/itsdi/article/view/6

\begin{abstract}
In the rapid development of 4.0 technology, now all aspects and types of activities have begun to utilize the presence of increasingly sophisticated technology to facilitate the activities, including the utilization of technology in the world of education. However, the application of technology in primary schools has not been able to be used properly, one of them in supporting the government program is 2013 curriculum. Based on the observation done at SDN Sukanagara and the study of the literature, in the process of processing competency values of students ' social and spiritual attitude is still less efficient, because assessment and input value still use the method Conventional time consuming and using a lot of paper on its process. In an effort to support the paperless program, utilization of technology for Attitude Competency Assessment in 2013 curriculum is needed, so there needs to be a system that can facilitate the assessment process of attitude competency that is more concise, efficient and Paperless. In this study there are 3 (three) methods used: Observation, library study, and prototyping. The results of this research in the form of prototype input competency assessment of social and spiritual attitude is packaged in the form of questionnaire, which is expected to assist in the processing of assessment data.
\end{abstract}

Keyword-, competency assessment, curriculum 2013, prototyping, education

\section{Introduction}

To realize an intelligent, self-reliant, good millennial generation and hold fast to social and spiritual value. Thus the government in cooperation with the Department of Education and Culture to innovate in the field of education is holding the 2013 curriculum. [1] In 2013 the government, through the Ministry of Education and Culture, made changes in the field of education in the form of new curriculum, better known as the 2013 curriculum. [2] The 2013 curriculum is a different curriculum from the previous curriculum that has different directions and paradigms. Namely in the year 2004 competency based curriculum (CBC) and in the year 2006 Education Unit level Curriculum (KTSP). [3] The curriculum is a medium that can determine the direction of a successful education. Whether an education is obtained depends on what curriculum to use. The curriculum is an implementation of teaching and learning activities. The 2013 curriculum is a curriculum developed from the previous curriculum and was implemented in 2013/2014, in the year 2004 competency-based curriculum and education unit level in 2006. The differentiation point between the 2013 curriculum and the previous curriculum is on the improvement and balance of soft skills and hard skills, including the competency, skill, and 
knowledge competencies. In LAW No. 20 of 2003 on National Education System (SISDIKNAS) mentioning the curriculum is a plan and regulation regarding the purpose, content, and direction of referrals that must be done and as an organizer of the learning process to achieve the objectives Specific education. The development of curriculum progress is crucial in the advancement of Science, technology, and cultural arts as well as changes in the local, national, regional and global communities in the future. Various changes and a progress result in internal and external challenges in the world of education. Therefore, the implementation of curriculum 2013 is an important step in facing the demands of people in the era of globalization in the future including the people of Indonesia itself. [4] On the curriculum aspect evaluation is very concerned, considering that evaluation is used as a tool to measure the level of ability of students in addition to being used to understand the daily changes in student life. The 2013 curriculum is essential in the self-assessment system, where learners can assess their own abilities. [5] The 2013 curriculum divides the attitude competencies into two aspects including spiritual attitude and social attitude despite the fact that both aspects are intertwined with one another. Spiritual attitude is a tendency to respond consistently. In the process, the attitude assessment with the observation method and questionnaire method is very helpful and summarizes the teaching force of each student's attitude assessment process. Questionnaires are also used to obtain information about the respondents ' attitudes, opinions, hopes and wishes. [6] On the curriculum 2013 the competence of attitudes, both the spiritual attitude (KI 1) and social attitudes (KI 2) are not taught in the teaching and learning process (PBM). Which means the competency of the attitude despite having basic competence, but not outlined in the material or concept presented in the learning process to the learners consisting of core activities and closing activities[ 7]

Self-assessment and inter-friend scoring can be done in order to build and shape the character of learners. The result of self-assessment and inter-friend assessment will be used as one of the confirmation data of the teacher's assessment results. Attitude assessment is not only the responsibility of religious teachers and counseling teachers who teach about ethics. Rather, all educators, and teachers are obliged to conduct an attitude judgment on the development of learners ' spiritual and social attitudes. Assessment is a very important component in the process of organizing the education. The improvement of education quality is considered by improving the quality of learning and the quality of the assessment system in the 2013 curriculum.

\section{Research Method}

In the research methods are used to achieve the objectives to obtain the accurate and trustworthy information required by a researcher to perform several phases in a study. [8] In an effort to solve the problems faced by the authors, and to achieve the objectives of the research methods used using 3 (three) methods of research, namely:

1. Observation methods

2. Library Studies

3. Prototyping methods.

Tables and Figures are presented center, as shown below and cited in the manuscript.

\subsection{Observation}

Observation is an empirical scientific activity written based on the facts of the field or text, through the experience of a five senses without manipulation of any data or facts. [9] Setting the research location is one of the most important in the research observation process, with the establishment of research site means that objects and objectives are established so as to facilitate the author in conducting Research. The authors of this study chose research locations at SDN Sukanagara, Cikupa District, Tangerang Regency, Banten province. The author will design a system of assessment information on the social and spiritual assessment of web-based students, which will be used by SDN Sukanagara The design of this application system consists of 5 (five), namely:

1. Teacher Data.

2. Student Data. 
IAIC Transactions on Sustainable Digital Innovation (ITSDI)

Vol. 1 No. 1 October 2019

3. Basic competency Data in the form of questionnaire.

4. Social attitude value Data.

5. Spiritual student Data.

\subsection{Library Studies}

The effort to improve the assessment system as the media of the input and spiritual value of students of SDN Sukanagara based on the web is a few literature reviews that the authors prepare to identify the subject of previous studies Been done. Some of the literature reviews include the following:

1. This research was conducted by Ni Putu Ariantini, I Nengah Suandi, I Made Sutama in the year 2014 under the title "Implementation of integration of Spiritual and social attitudes in Indonesian language learning based curriculum 2013 in class VII of SMP Negeri 1 Singaraja" . This research discusses the barriers faced during the process of the Plementasian spiritual attitude and social attitudes in the learning process, barriers to planning, which is the teacher has difficulty in determining $\mathrm{KD}$ from $\mathrm{KI} 1$ and $\mathrm{KI} 2$ to Integrated. [10]

2. This research was conducted by Hesty Puspita Sari, Retno Muhartini in the year 2017 with "the title of the application processing system value of SDN Tanjunganom 2 Tanjunganom Nganjuk)" This study commented on the development of valueprocessing applications Computerised roads are taken in the process of processing data and information by utilizing (Microsoft Excel). Application processing value Raport. The processing of this value encompasses the spiritual, social, knowledge per basic competence and skills of the basic competence, including also the students ' extracurricular, personality and absence of students. [11]

3. This research was conducted by Luqman Azhar Juliantri, Totok Sumaryanto Florentinus, Hari Wibawanto in the year 2017 titled "Development of E-Report curriculum 2013 Web-based at SMK Negeri 1 Slawi" This study discusses the valuation method in the format Writing reports on the 2013 curriculum that aims to create a more complex, this research aims to set up a WEB-based raport model, E-player ratings, and this research is conducted to determine the level of efficiency and effectiveness of the Systems developed. [12]

4. This research was conducted by Imron Rosadi in 2018 under the title "Classification of character based on social attitude assessment of peer friends on curriculum 2013 utilizing Naive Bay" This study designed a social attitude assessment to know The character of each student, the assessment of social attitudes between the peers in the form of irregular sentences and the teacher will classify to determine the character of each student. [13]

5. This research was conducted by Mawardi in 2014 with the title "Implementation of curriculum of SD/MI year 2013 and the implications of efforts to improve the learning process through PTK" This study commented on the 2013 curriculum for SD/MI level with How to improve the approach, model and standards of the learning process, and how to structure the assessment process. There are two main components to this learning system, a component very closely related to improving the quality of learning. The Model and standards of a teaching learning process are interconnected with the assurance of whether the learning process is accurate, while the assessment components are accurately related to the quality measurement. [14]

6. The study was conducted by Lukmanul Hakim Abdullah in 2017 under the title of assessment system in Curriculum 2013: Study of the document "This study discusses about national education system, discussing that the function of national education is "aims to form students ' character, develop skills, and dignity in order to educate the life of the nation. [15]

7. The research was conducted by Untung Rahardja, Qurotul Aini, Alfiah Khoirunisa in 2017 with the title "This study commented on the Pen system (attendance Assessment) using the YII Framework-based website, to facilitate the guiding lecturers in Recording 

IAIC Transactions on Sustainable Digital Innovation (ITSDI)

Vol. 1 No. 1 October 2019

8. and measuring the attendance of study tutoring students, Pen system (attendance Assessment) will present information in the form of charts using Highchart. [16]

9. This research was conducted by Egia Rosi Subhiyakto, Danang Wahyu Utomo in the year 2017 under the title "Analysis and Design application modeling needs software using Prototyping method" This study discusses about application modeling Relatively expensive on the market, resulting in analysts experiencing problems in modeling needs, especially for a beginner analyst. A beginner analyst in general faces difficulties in applying their knowledge if the application used is too complex and difficult to understand. The available applications are also more devoted to the world of industry, and rarely are applications aimed at education. [17]

\subsection{Prototyping}

Prototyping is a method of software development, which forms the physical model of the system and has the function as the initial version of the system. Using this prototyping method will result in an overview of the system as an intermediary for developers and users to be able to interact in the process of information system development activities. [18] In this study using several stages of the authors, in this study there are 3 (three) stages of requirement analysis and definition, phase user interface prototyping, Architecture \& component Design and Prototyping. [19]

1. Phase Requirement analysis and definition. At this stage, a study of the problems that occurred in the research object. The study of the problem was conducted using Pustaka study, interview with SDN Sukanagara. In addition to conducting research on the problem, the authors also examine the needs, this study needs will be used as a tool that will later be used in the process of making prototypes.

2. Phase User interface Prototyping. After reviewing the needs of the system, at this stage the author performs recognition or identifying back to the needs of the system. If the system needs have been well identified, the next process is the creation of a user interface prototype. This User interface prototype is an interaction and initial look of an application built.

3. Phase Architecture \& Component design and prototyping. Once the prototype user interface has been completed, the next process will be to create a design and prototype architecture and components of the application components to be built and later used as a reference for creating the final application.

\section{Findings}

\subsection{Problem Analysis}

SDN Sukanagara is a state elementary school in Cikupa District, Tangerang Regency, Banten province, but it has been found the problem in the process of input assessment of social and spiritual attitudes and should seek solutions in order to solve Problem to facilitate the process of input value. KTSP and K13 curriculum has a significant difference can be seen from the second difference of these results. In the KTSP curriculum the assessment process is more visible in terms of basic knowledge of students only, while in the curriculum 2013 assessment process is done authentically, by measuring all aspects of competence in terms of knowledge, attitudes, and all Students ' skill aspects. 

IAIC Transactions on Sustainable Digital Innovation (ITSDI)

Vol. 1 No. 1 October 2019

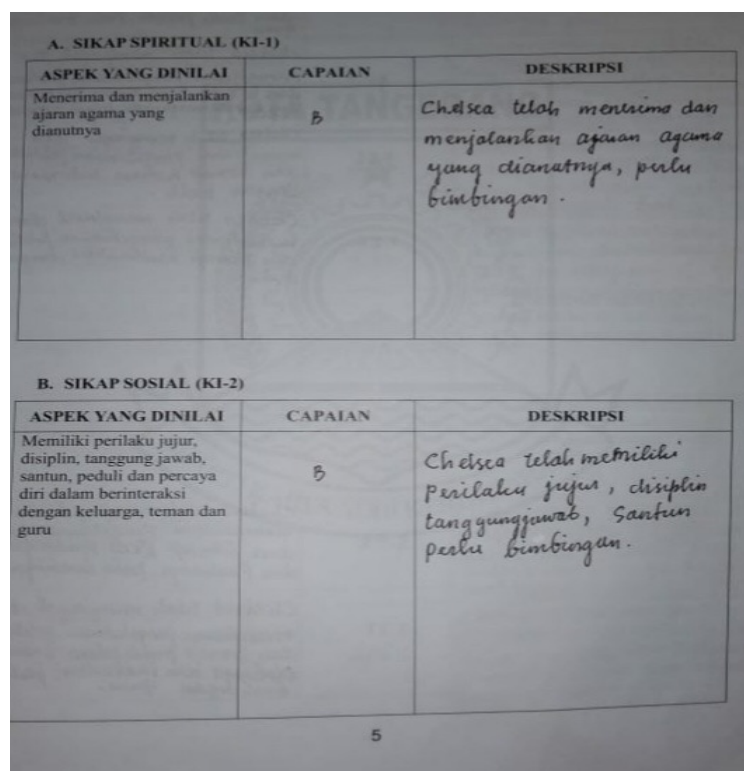

Picture 1. 2013 curriculum raport which uses conventional methods

Picture above is an example of a picture sheet Raport curriculum 2013 in aspects of assessment of social and spiritual attitudes that still use conventional methods, which are visible in the column of notes that still use paper and teaching personnel to take notes Assessment of Student attitudes competency.

\subsection{Troubleshooting}

3.2.1 Login prototype page (Program overview)

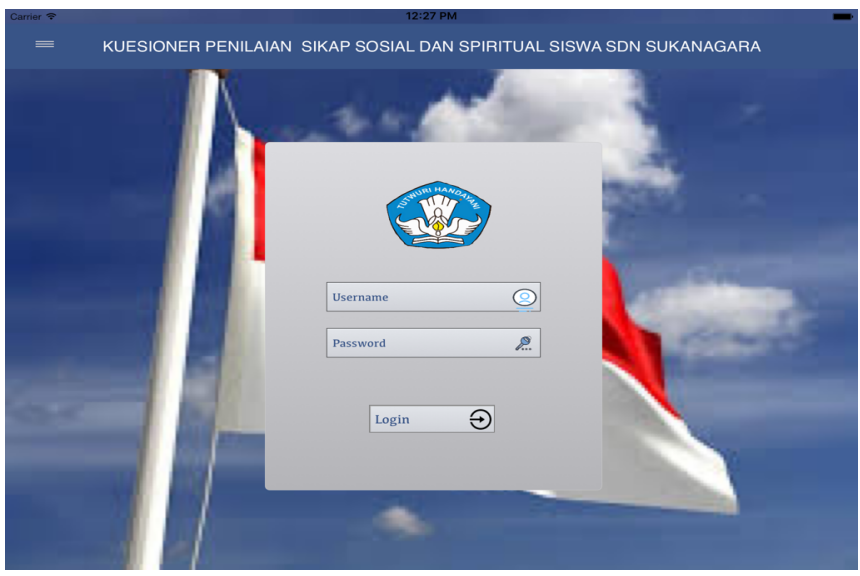

Picture 2. Prototype Login View

To be able to operate the system a respondent or teacher has access to enter the login by entering a username or password.

\subsubsection{Views after successful login}


IAIC Transactions on Sustainable Digital Innovation (ITSDI)

Vol. 1 No. 1 October 2019

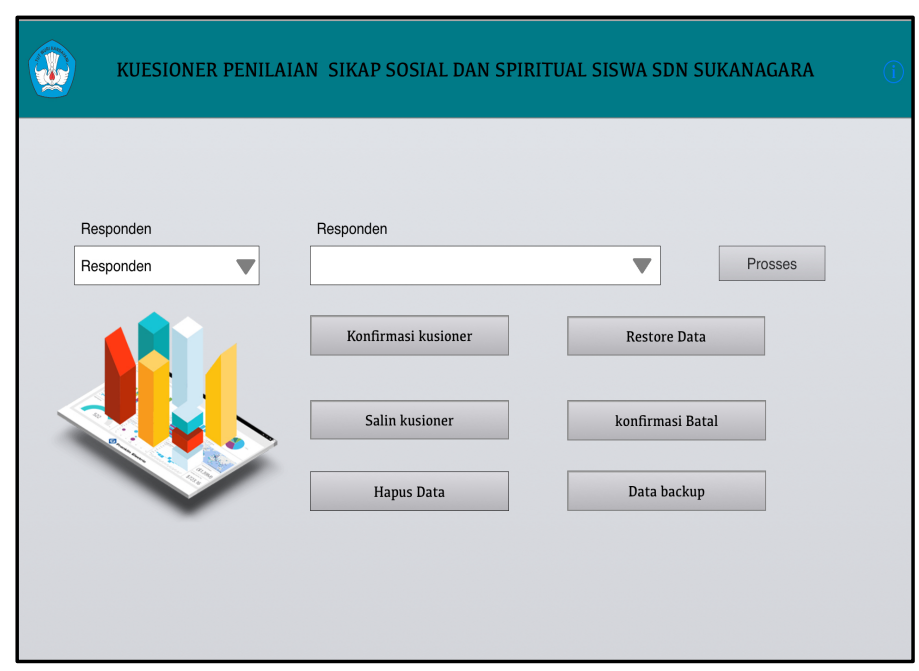

picture 3. Prototype Display after successful login

After the successful login will appear such a view is a instructions to fill the respondent data that can be filled by the principal, teacher or class guardian after which the respondent can choose the menu confirmation questionnaire to perform the competency assessment of the attitude.

\subsubsection{Page Views Social Attitude Competency assessment}

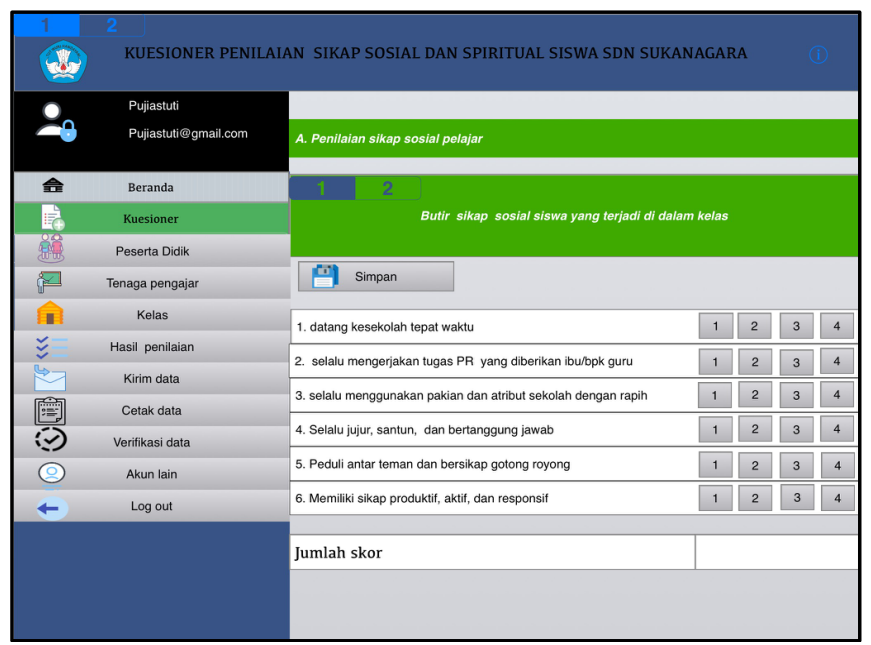

picture 4. Format of social attitudes assessed in the form of questionnaires

After the respondent confirms the questionnaire, it will show the evaluation aspect of the attitude that can be filled by the class or teacher, which will be filled according to the attitude of students while in the school environment, this questionnaire is filled in While the teaching and learning activities take place by scoring from 1 to 4 each of them has a different judgment. 
IAIC Transactions on Sustainable Digital Innovation (ITSDI)

Vol. 1 No. 1 October 2019

Scoring Score:

* (1 Score) TP = Never

* (2 Score) JR = Infrequent

* (3 score) SR = frequently

* (4 Score) SS = very frequent

\subsubsection{Page Views Spiritual Attitude Competency Assessment}

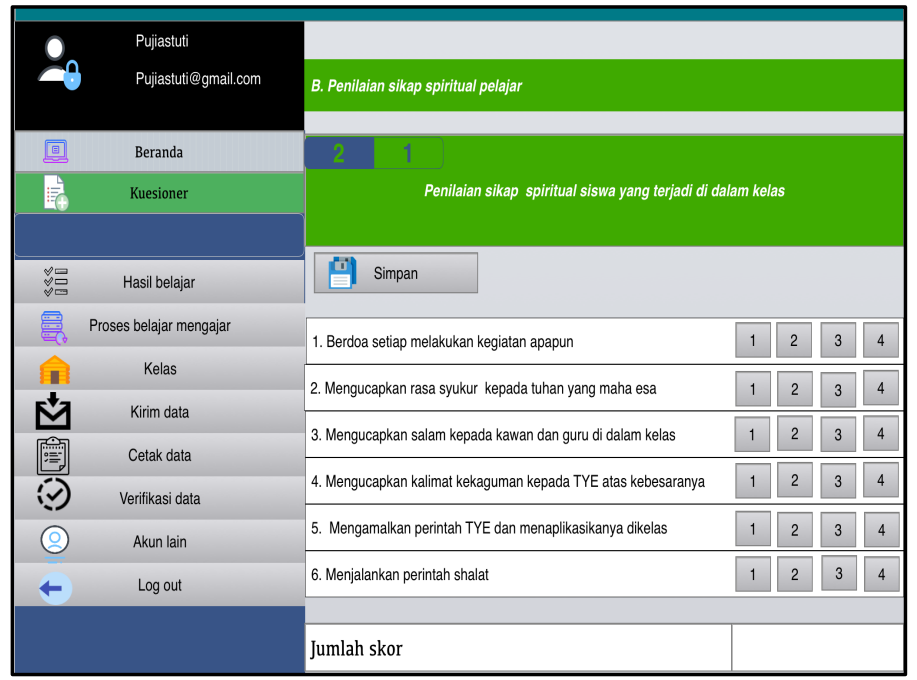

picture 5. Format of the spiritual attitude assessed in the form of questionnaires

The judging aspect format is a spiritual attitude that can be filled by the class or the teacher, which will be filled in accordance with the attitude of students while in the school environment, this questionnaire is filled when learning activities take place with a Score from 1 to 4 which each has a different rating.

Scoring Score:

* (1 Score) TP = Never

* (2 Score) JR = Infrequent

* (3 score) SR = frequently

* (4 Score) SS = very frequent

*

\subsection{5 page views Assessment of social and spiritual attitudes of learners}



IAIC Transactions on Sustainable Digital Innovation (ITSDI)

Vol. 1 No. 1 October 2019

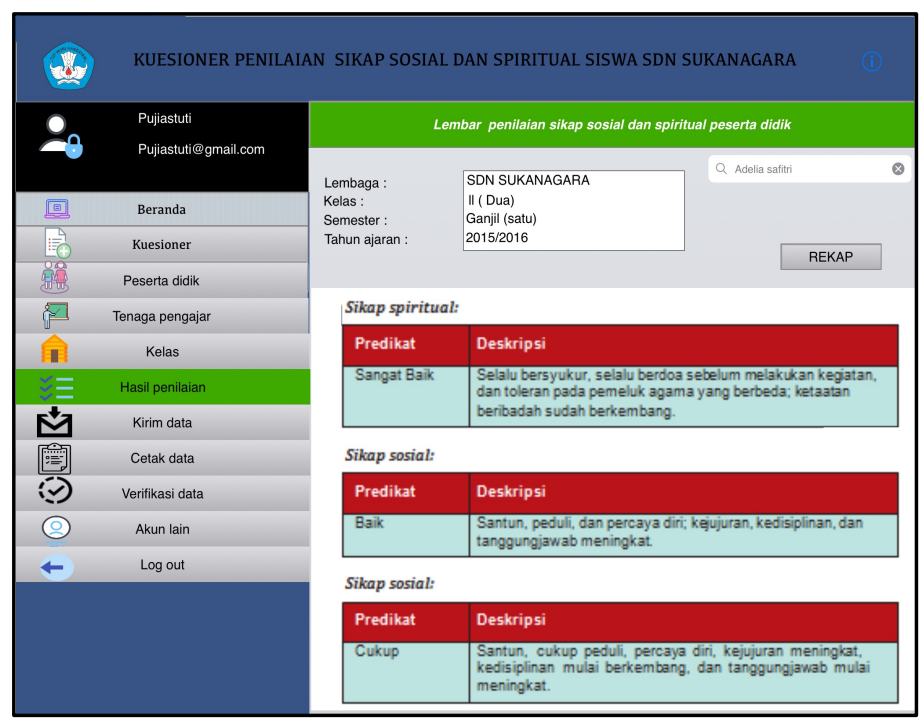

picture 6. Student social and spiritual attitudes assessment sheet

The Format of a social attitude sheet judged by a teacher's assessment of the student's behaviour in the learning process that encompasses spiritual and social attitudes is reported in this kind of form.

\subsection{6 page views Assessment of social and spiritual attitudes of learners}

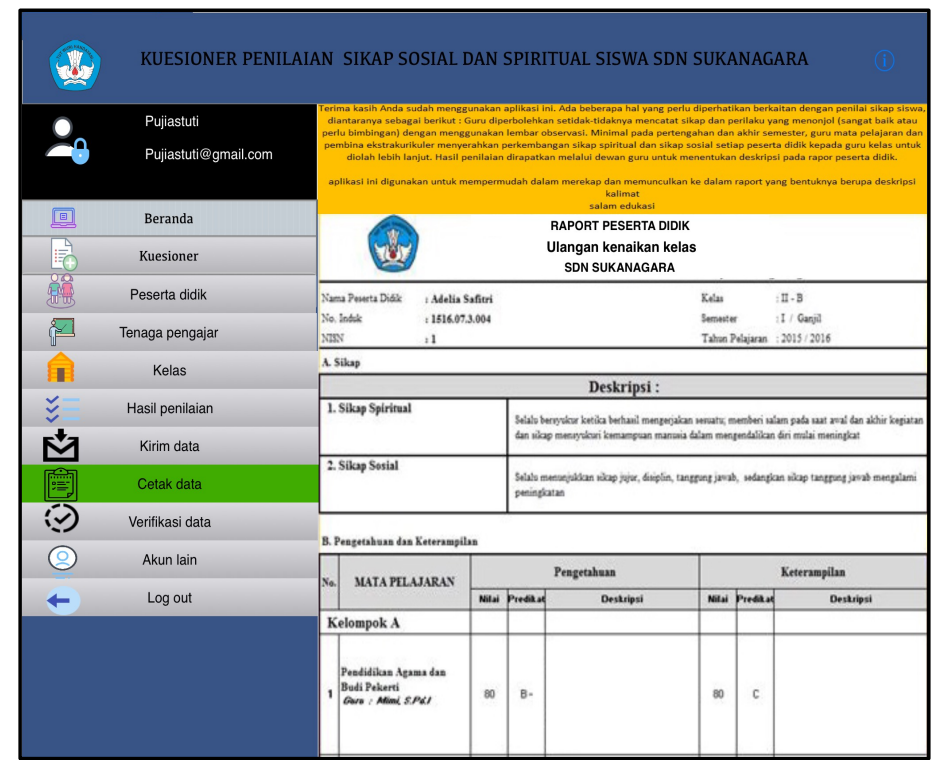

picture 7. Page of final assessment sheet

The final scoring sheet format will be recap at the end of the semester. A value recap will sum the score according to the Student Attitude Competency assessment, and the result will be reported at the end of the term in the form of a caption and complete with its description. 


\section{Conclusion}

This is expected to demonstrate whether research can be achieved in accordance with the purpose of the system. In the application of the methods used can determine the influence of achieving effectiveness and efficiency of assessment with the system used to facilitate a teacher or a guardian in the value of social and spiritual attitudes. In the process of recording the grades of students conducted by a method (questionnaire) begins with determining the value of attitude criteria for each criteria, determining the influence of students ' social and spiritual attitudes in the calculation of value. Information systems Assessment of social and spiritual attitudes of students at SDN Sukanagara is expected to assist the school, especially the student guardian in recording the value of students ' attitudes quickly and efficiently.

\section{References}

[1] Merindasari, E., Widyaningtyas, T., \& Arifin, M. Z. (2015). Sistem Informasi Penilaian Akademik Siswa Kurikulum 2013 Berbasis Web di SMAN 1 Trenggalek. SESINDO 2015, 2015.

[2] Sari, H. P., \& Muhartini, R. (2017). Sistem Aplikasi Pengolahan Nilai Raport SDN Tanjunganom 2 Kecamatan Tanjunganom Nganjuk. ANTIVIRUS: Jurnal IImiah Teknik Informatika, 11(1).

[3] Juliantri, L. A., Florentinus, T. S., \& Wibawanto, H. (2017). Pengembangan e-Rapor Kurikulum 2013 Berbasis Web di SMK Negeri 1 Slawi. Innovative Journal of Curriculum and Educational Technology, 6(1), 11-16.

[4] Rosadi, I. (2018). KLASIFIKASI KARAKTER BERDASARKAN PENILAIAN SIKAP SOSIAL TEMAN SEJAWAT PADA KURIKULUM 2013 MEMANFAATKAN NAIVE BAYES. Jurnal Teknika, 10(2), 1021-1026.

[5] Mawardi, M. (2014). Pemberlakuan Kurikulum SD/MI Tahun 2013 dan Implikasinya Terhadap Upaya Memperbaiki Proses Pembelajaran Melalui PTK. Scholaria: Jurnal Pendidikan dan Kebudayaan, 4(3), 107-121.

[6] Febriyanto, E., Handayani, I., \& Suprayogi, D. (2019). Aplikasi Sistem Penilaian Penguji Berbasis YII Framework Sebagai Media Input Nilai Mahasiswa Sidang Tugas Akhir Dan Skripsi Pada Perguruan Tinggi. CSRID (Computer Science Research and Its Development Journal), 10(2), 111-123.

[7] Ariessanti, H. D., Martono, A., \& Suprayogi, D. (2019). SISTEM INFORMASI PROFIL MAHASISWA PADA PENILAIAN PENGUJI PESSTA+ DI PERGURUAN TINGGI. CERITA Journal, 5(1), 76-88.

[8] Abdullah, L. H. (2017). Sistem Penilaian dalam Kurikulum 2013: Kajian Dokumen Terhadap Kurikulum 2013.

[9] Subagia, I. W., \& Wiratma, I. G. (2016). Profil penilaian hasil belajar siswa berdasarkan kurikulum 2013. JPI (Jurnal Pendidikan Indonesia), 5(1), 39-55.

[10] Ariantini, N. P., Suandi, I. N., Hum, M., \& Sutama, I. M. (2014). Implementasi Pengintegrasian Sikap Spiritual dan Sikap Sosial dalam Pembelajaran Bahasa Indonesia Berbasis Kurikulum 2013 di Kelas VII SMP Negeri 1 Singaraja. Jurnal Pendidikan dan Pembelajaran Bahasa Indonesia, 3(1). 
[11] Safitri, D., \& Oktaviana, M. (2017). Implementasi Penilaian Autentik Kurikulum 2013 (Studi Kasus Guru IPS di SMP Labschool Jakarta). Edukasi IPS, 1(1), 31-40.

[12] Sukma, M. R. (2018). PELAKSANAAN PENILAIAN SIKAP SPIRITUAL BERDASARKAN KURIKULUM 2013 DI SMP NEGERI 10 BANTIMURUNG (Doctoral dissertation, UNIVERSITAS NEGERI MAKASSAR).

[13] Pujihastuti, I. (2010). Prinsip Penulisan Kuesioner Penelitian. CEFARS: Jurnal Agribisnis dan Pengembangan Wilayah, 2(1), 43-56.

[14] Rahardja, U., Aini, Q., \& Khoirunisa, A. (2017). Implementasi Business Intelligence Menggunakan Highchart pada Sistem Penilaian Absensi berbasis YII Framework. CSRID (Computer Science Research and Its Development Journal), 9(2), 115-124.

[15] Hasanah, H. (2017). Teknik-teknik observasi (sebuah alternatif metode pengumpulan data kualitatif ilmu-ilmu sosial). At-Taqaddum, 8(1), 21-46.

[16] Subhiyakto, E. R., \& Utomo, D. W. (2017). Analisis dan Perancangan Aplikasi Pemodelan Kebutuhan Perangkat Lunak Menggunakan Metode Prototyping.

[17] Purnomo, D. (2017). Model Prototyping Pada Pengembangan Sistem Informasi. JIMPJurnal Informatika Merdeka Pasuruan, 2(2).

[18] Pradipta, A. A., Prasetyo, Y. A., \& Ambarsari, N. (2015). Pengembangan Web ECommerce Bojana Sari Menggunakan Metode Prototype. eProceedings of Engineering, 2(1).

[19] Rahardja, U., Aini, Q., Apriani, D., \& Khoirunisa, A. (2019). Optimalisasi Informasi Manajemen Laporan Assignment Pada Website Berbasis Content Management System. Technomedia Journal, 3(2), 213-223.

[20] Rahardja, U., Aini, Q., \& Zebua, V. K. A. (2019). Penerapan Sistem Pengecekan Mahasiswa Layak KKP Berbasis YII Framework Pada Perguruan Tinggi. Jurnal Teknoinfo, 13(2), 96-99.

[21] Rahardja, U., Aini, Q., \& Khoirunisa, A. (2019). Monitoring Kinerja User Akuntan Menggunakan Dashboard Pada Web Based Accounting Online di Perguruan Tinggi. SATIN-Sains dan Teknologi Informasi, 4(2), 58-62. 